\title{
Movement patterns of humpback whales (Megaptera novaeangliae) reoccupying a Brazilian breeding ground
}

\author{
Maria Isabel Carvalho Gonçalves ${ }^{1,2}{ }^{\circledR}$, Renata Santoro de Sousa-Lima ${ }^{2}$, Niel Nascimento Teixeira ${ }^{3}$, \\ Gustavo Henrique Carvalho ${ }^{1,4}$, Daniel Danilewicz, ${ }^{5,6,7}$, Júlio Ernesto Baumgarten ${ }^{8,9}$ \\ ${ }^{1}$ Universidade Estadual de Santa Cruz, Programa de Pós-Graduação em Ecologia e Conservação da Biodiversidade, \\ Ilhéus, BA, Brasil \\ ${ }^{2}$ Universidade Federal do Rio Grande do Norte, Laboratório de Bioacústica, Departamento de Fisiologia e \\ Comportamento, Centro de Biociências, Natal, RN, Brasil \\ ${ }^{3}$ Universidade Estadual de Santa Cruz, Departamento de Ciências Agrárias e Ambientais, Ilhéus, BA, Brasil \\ ${ }^{4}$ Universidade Estadual Paulista, Departamento de Botânica, Rio Claro, SP, Brasil \\ ${ }^{5}$ Universidade Estadual de Santa Cruz, Programa de Pós-Graduação em Zoologia, Ilhéus, BA, Brasil \\ ${ }^{6}$ Instituto Aqualie, Juiz de Fora, MG, Brasil \\ ${ }^{7}$ Grupo de Estudos de Mamíferos Aquáticos do Rio Grande do Sul, Osório, RS, Brasil \\ ${ }^{8}$ Universidade Estadual de Santa Cruz, Laboratório de Ecologia Aplicada e Conservação Ilhéus, BA, Brasil \\ ${ }^{9}$ Universidade Estadual de Santa Cruz, Departamento de Ciências Biológicas Ilhéus, BA, Brasil \\ *Corresponding author: Maria Isabel Carvalho Gonçalves,e-mail: misabelcgoncalves@gmail.com
}

GONÇALVES, M. I. C., SOUSA-LIMA, R. S., TEIXEIRA, N. N., CARVALHO, G. H., DANILEWICZ, D., BAUMGARTEN, J. E. Movement patterns of humpback whales (Megaptera novaeangliae) reoccupying a Brazilian breeding ground. Biota Neotropica. 18(4): e20180567. http://dx.doi.org/10.1590/1676-0611-BN-2018-0567

\begin{abstract}
The population of humpback whales from breeding stock A is increasing, and little is known about the routes used by humpbacks that move north of the main calving area of Brazil, the Abrolhos Bank. The aim of this study was to describe the movements of humpback whales in a reoccupation wintering area (Serra Grande, Bahia state, Brazil) based on land-based surveys to test if movement patterns change during the season and between years, due to group composition, behavioral state, and distance to the coast. The mean leg speed of the groups sighted was $6.88( \pm 2.92) \mathrm{km} / \mathrm{h}$, and leg speed was positively correlated with distance to the coast. There was an increase in leg speed and distance to the coast with increasing number of escorts in the groups with calves. The mean linearity value for group trajectory was $0.81( \pm 0.19)$ and the mean reorientation rate was $25.72( \pm 19.09) \%$ min. We observed a predominance of trajectories heading south throughout the study. Groups exhibiting more erratic movements early in the season, and groups moving south showed more linear trajectories than groups moving north, indicating the beginning of their migration back to the feeding grounds. Energy conserving strategies and social context affect the movements of humpback whales in Serra Grande, resulting in the observed patterns of the reoccupation of available and suitable habitat north of Abrolhos. Thereby, special attention should be given managing activities with the potential to disturb or displace whales using the region to calve and breed. Keywords: calving area, distance to the coast, land-based station, linearity, speed.
\end{abstract}

\section{Padrões de movimento das baleias-jubarte (Megaptera novaeangliae) reocupando uma área reprodutiva brasileira}

Resumo: A população das baleias-jubarte do estoque reprodutivo A está aumentando, e pouco se sabe sobre as rotas usadas pelas baleias que se movem a norte da maior área de reprodução do Brasil, o Banco dos Abrolhos. O objetivo deste estudo foi descrever os movimentos das baleias-jubarte em uma área de reocupação (Serra Grande, estado da Bahia, Brasil) através do monitoramento por ponto fixo para testar se os padrões de movimento mudam ao longo da temporada e entre os anos, devido à composição de grupos, estado comportamental, e distância à costa. A média da velocidade da pernada dos grupos observados foi de $6,88( \pm 2,92) \mathrm{km} / \mathrm{h}$, apresentando uma correlação positiva com a distância à costa. Houve um aumento da velocidade da pernada e da distância à costa com o aumento do número de escortes nos grupos com filhotes. A linearidade média das trajetórias dos grupos foi de $0,81( \pm 0,19)$ e a taxa média de reorientação foi de $25,72( \pm 19,09) \%$ min. Observamos uma predominância das rotas com rumo para sul ao longo do estudo. No início da temporada, os grupos apresentaram movimentos mais erráticos, e os grupos se deslocando para sul apresentaram trajetórias mais lineares que grupos se movendo para norte ou para outras direções, indicando o início da migração de volta ao seu sítio alimentar. Estratégias para economizar energia e o contexto social afetam o movimento das baleias-jubarte em Serra Grande, resultando nos padrões observados de reocupação de habitat disponível e adequado a norte de Abrolhos. Desse modo, uma atenção especial deve ser dada para a gestão de atividades com o potencial para perturbar ou deslocar as baleias que usam a região para se reproduzir.

Palavras-chave: berçário, distância à costa, linearidade, ponto fixo, velocidade. 


\section{Introduction}

Humpback whales (Megaptera novaeangliae Borowski, 1781) are migratory except for the Arabian Sea population (Mikhalev 1997), reproducing in warmer waters (Rasmussen et al. 2007) of low latitudes during the winter and feeding in cooler waters during the summer (Dawbin 1966; Clapham 2000). In calving areas, humpback whales often concentrate near the coast, islands and reef banks (Dawbin 1966; Herman 1979; Clapham 2009). Proximity to the coastline ensures shallow water (Ersts \& Rosenbaum 2003; Cartwright et al. 2012) and protection from predators (Corkeron \& Connor 1999), providing ideal conditions for whales to calve and nurse (Whitehead \& Moore 1982; Craig et al. 2014).

Humpbacks have different movement patterns depending on their location and the phase of their life cycle (breeding, migrating or feeding). They tend to move at a lower speed in both feeding and breeding areas than in migratory corridors, even for mother and calf groups (Lagerquist et al. 2008; Kennedy et al. 2014), and also more erratically in feeding areas than in migratory corridors (Zerbini et al. 2006). This may be related to search/encounter patterns when mating or feeding. However, Dalla Rosa et al. (2008) suggested that variation in speed of humpback whales may occur due to individual behavioral patterns than to common patterns that differ among the areas or life stages. Tyack \& Whitehead (1983) observed increased speed and straighter tracks with increasing group size. Coastline orientation seems to be a key factor that influences the trajectories of humpback whales at least for same populations (Dawbin 1956; Findlay et al. 2011), where whales move following its orientation.

Humpback whales from the breeding stock A (BSA) (IWC 2005) migrate from their feeding area off South Georgia and South Sandwich Islands (Engel \& Martin 2009; Zerbini et al. 2011) to breed along the Brazilian coast between June and November (Martins et al. 2001). The main breeding area of humpback whales in Brazil is the Abrolhos Bank (Andriolo et al. 2010). Nevertheless, the population is increasing (Bortolotto et al. 2016; Pavanato et al. 2017) and areas used before the whaling period are being reoccupied (Rossi-Santos et al. 2008).

While migration routes used by humpback whales leaving the Brazilian breeding ground towards the feeding areas are almost a straight course of $170^{\circ}$ (Zerbini et al. 2006; Horton et al. 2011; Zerbini et al. 2011), information on the small-scale movement patterns of humpbacks in the wintering grounds is still scarce. The understanding of the influence of environmental features and social context on the behavior of humpback whales could explain their fine-scale movement variability (Kavanagh et al. 2016). It may shed light on questions related to individual/group small-scale movement, and on within-season movement, especially with the expansion of the Brazilian breeding ground. The availability of appropriate habitat may influence the distribution of humpback whales that sometimes can only be verified at local and fine-scales (Rasmussen et al. 2007).

Serra Grande still has low anthropic activity and exhibits similar geomorphological characteristics to the remaining northeast and east coast north of Abrolhos, where the increased density of humpback whales has been observed (Bortolotto et al. 2017), contrasting with the extensive continental shelf of the main breeding area. This study will allow us to verify the plasticity of the population from BSA to the availability of habitat with different characteristics as the number of humpback whales is increasing.
Land-based surveys offer methods that allow the tracking of humpback whales without interfering with their behavior (Würsig et al. 1991; Sagnol \& Reitsma 2014). This methodology has been used to study habitat use (e.g. Smultea 1994; Danilewicz et al. 2016), the effect of whale watching (e.g. Williams et al. 2002; Schaffar et al. 2009), and group movement patterns (e.g. Best et al. 1995; Bailey \& Thompson 2006). It has been noted that movement parameters such as speed and net course may be measured in land-based surveys with the same accuracy as boat surveys (Godwin et al. 2016).

The aim of this study was to characterize the movements of humpback whales in the Serra Grande region. It will provide a baseline information for movement patterns in the reoccupation areas that present the main features of the Brazilian coast north of the Abrolhos Bank, in order to test the hypothesis if spatio-temporal and behavioral factors influence on the movement patterns of the whales in this wintering area.

\section{Material and methods}

\section{Study area}

Data were collected from a land-based observation station in Serra Grande (1428'30" S; 3901'50” W), Bahia state, Northeastern Brazil. The platform is $93 \mathrm{~m}$ above the sea level and is $315 \mathrm{~m}$ from the shoreline. The radius of observation from the land-based station was $15 \mathrm{~km}$, between azimuths 70 and $184^{\circ}$, covering a surface area of $224.5 \mathrm{~km}^{2}$ (Figure 1). The orientation of the coastline, the presence of rocky coast and vegetation reduced the monitoring of northern areas.

The study area is on the narrowest continental shelf of the Brazilian coast (Amorim et al. 2011; IBGE 2011), reaching $100 \mathrm{~m}$ depth at approximately $14 \mathrm{~km}$ from the coastline (Figure 1). Depth increases with increasing distance to the coast (Gonçalves et al. 2018). The dominant southward Brazil Current occurs from October to March, and the northward North Brazil Undercurrent occurs from April. However, there is an inversion of the predominant current from north to south from August (Rezende et al. 2011). These flows close to the shelf break are expected to interact with the shelf currents due to its narrow width (Amorim et al. 2011).

\section{Visual surveys}

The visual monitoring of humpback whales was conducted during the breeding season from July to October in the years 2014 and 2015. Data were collected during daytime between 07:22 am and 04:40 pm when weather conditions were favorable ensuring visibility and during sea state below or equal to 4 on the Beaufort scale. The focal animal sampling methods were used when solitary individuals were sighted, and a focal group approach was used when 2 or more individuals were sighted (Mann 1999). Focal follows lasted until the whales moved out of the study area or if visibility became an issue, affecting the quality of observation (Morete et al. 2003). In the presence of more than one group in the area, the one chosen was based on the surface and active behavior of the individuals and then by the proximity of the groups to the coast. A total station TOPCON ES105 with 5' of precision and 30-power monocular magnification was used to track the groups. Group size and composition, time, angles and behavioral states were recorded. Events of individuals merging and/or splitting of the groups 


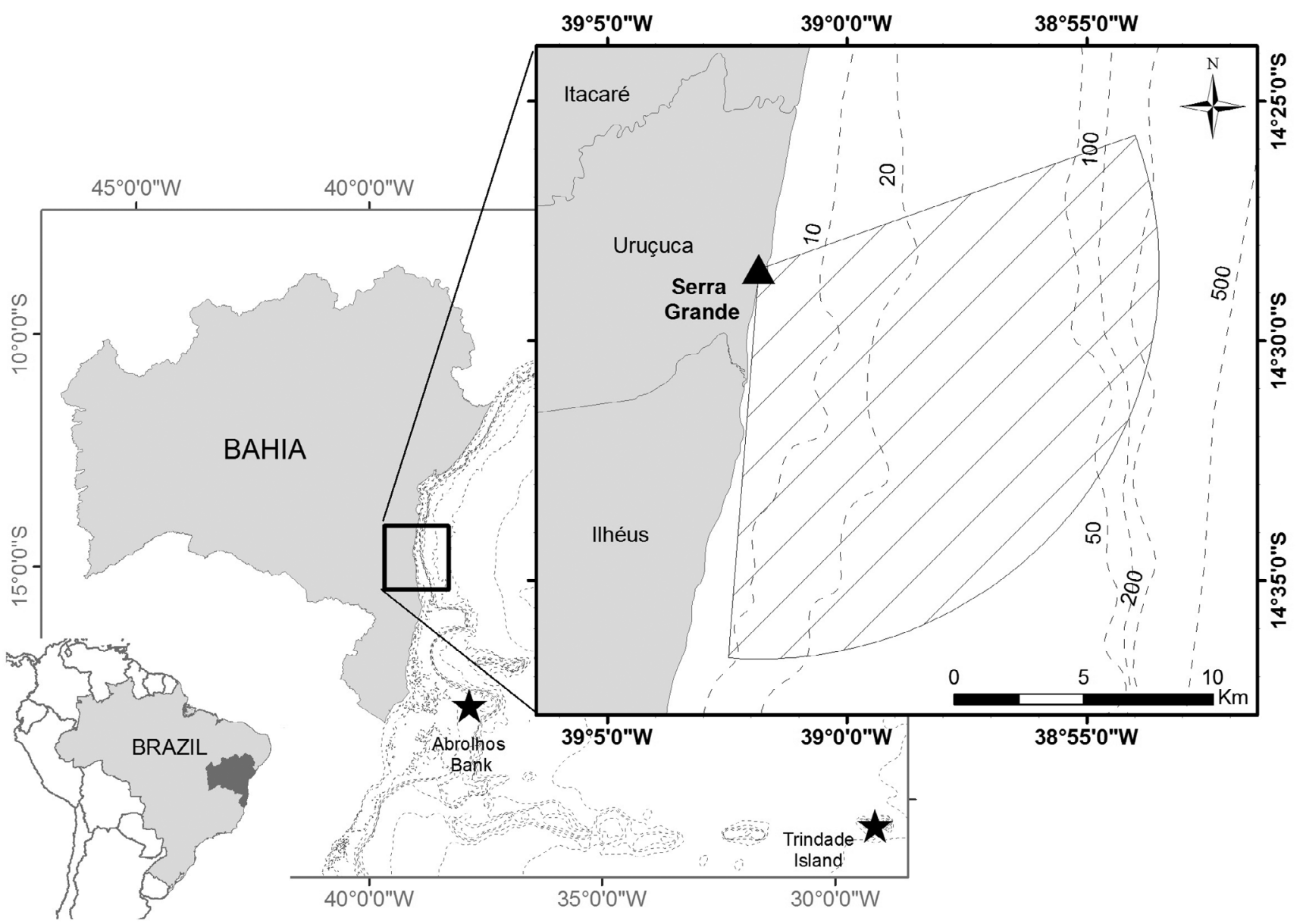

Figure 1. Serra Grande study area located in North-eastern Brazil where surveys occurred from a land-based observation station at a height of $93 \mathrm{~m}$ with $15 \mathrm{~km}$ radius, covering $224.5 \mathrm{~km}^{2}$ (shaded area).

were also recorded. In those cases, focal sampling continued with the group selected for tracking which was considered a new group (Best et al. 1995; Barendse et al. 2010). In the presence of more than one individual, the angles were taken from the leading individual (directing the movement) or from the calf when present.

The land-based team was comprised of two or three observers: the principal observer (the same person throughout the study) who operated the total station; a second observer who registered data; and a third observer, who followed the group with the aid of $7 \times 50$ binoculars, checking if any other group appeared in the area or approached the focal group. Wind speed and direction, cloud cover and sea state on the Beaufort scale were registered every 30 minutes or when weather conditions changed. The presence of boats in the region is very low so its occurrence was disregarded.

\section{Definitions}

A group was classified either as a single individual or an association of individuals based on a distance of up to $100 \mathrm{~m}$ from each other and if all individuals were moving in the same general direction with a coordinated behavior (Whitehead 1983; Morete et al. 2008).

We considered group composition as $1 \mathrm{AD}$, when a solitary adult was observed; dyad, a group of two adults; multiple group, three or more adults, MOC, a group of mother and calf; MOCE, when mother and calf were escorted by another adult; and MOCE/+, a group of mother, calf and two or more escorts (Morete et al. 2007a). Due to the observational distance from the groups, we considered two age classes: adult and calf.

Behavioral states were classified as resting - when the whale(s) remained on the surface of the water, exposing the dorsal fin and with no apparent movement; swimming - when the whales(s) alternated from being submerged and on the surface; and; active - when aerial displays occurred, as breaching, tail and pectoral slaps (Morete et al. 2003; Morete 2007).

\section{Spatial analyses}

A total station provides horizontal and vertical angles to an object, where the first angle is between the object and a known reference point, and the second between the observer and the object. These angles allowed the estimation of the distance between the observer and the object (Gailey \& Ortega-Ortiz 2002). Universal Transverse Mercator (UTM) coordinates from the total station and the reference point were measured with millimetric precision by Global Navigation Satellite System positioning. The orthometric altitudes of these points were determined by Geoidal MAPGEO 2010 model (Monico 2008). UTM coordinates (E, N) of all the measured points were calculated with the height of the total station and tidal variation through trigonometric equations (Gonçalves 2017). The horizontal distances (calculated from data collected by the total station) were transformed for spherical distances considering the curvature of the earth (Vanicek \& Krakiwsky 1996). 
Distances between the group and coastline were calculated using the distances to the meridians, taking into consideration the first position sampled of the group using Google Earth to have more precise values due to the higher resolution of the maps.

\section{Movement analyses}

We only considered those tracks for which four positions were sampled for at least $10 \mathrm{~min}$, and with group composition identified. The following parameters were calculated:

Leg speed: mean of speeds calculated between two consecutive positions divided by the distance between two positions and the time taken to travel between them (Barendse et al. 2010). Speeds above $30 \mathrm{~km} / \mathrm{h}$ were not considered since the maximum speeds recorded for humpback whale vary from $18 \mathrm{~km} / \mathrm{h}$ (Findlay \& Best 1996) to $27 \mathrm{~km} / \mathrm{h}$ (Zenkovich 1937 apud Winn \& Reichley 1985).

Net speed: calculated by dividing the linear distance between the first and last positions (net distance) and the total time of the track (Barendse et al. 2010; Findlay et al. 2011).

Linearity: index calculated by dividing the total distance between the first and last positions (net distance) by the sum of the distances between each position (cumulative distance) of the track (Williams et al. 2002; Gailey et al. 2007; Barendse et al. 2010). The values range from 0 to 1 with values closer to 0 representing more circular paths and values closer to 1 represent more direct trajectories (Schaffar et al. 2009; Burns 2010).

Reorientation rate: calculated as the sum of all absolute values of change of bearing between two consecutive positions, dividing by the total time of the track (Smultea \& Würsig 1995; Gailey et al. 2007). It represents the pattern of bearing that changes along a track line, in which higher values of reorientation indicate more erratic paths (Burns 2010).

Net course: the true bearing in degrees considering the first and last positions of the track (Best et al. 1995; Barendse et al. 2010; Findlay et al. 2011). We divided the net course into three classes: north (from $320^{\circ}$ to $50^{\circ}$ ), south (from $140^{\circ}$ to $230^{\circ}$ ) and other directions (between $50^{\circ}$ and $140^{\circ}$ and between $230^{\circ}$ and $320^{\circ}$ ), considering the coastline orientation.

Martins (2012) equations were used to calculate all parameters cited above. When we observed more than one behavioral state during the same track, leg speed and reorientation rate were calculated for each behavioral state separately.

\section{Statistical analyses}

Active groups with more than one individual were excluded $(n=16)$, except for analyses involving exclusively net course. The only exception to include active groups with more than one individual in the analyses was mother and calf groups when it was possible to follow the calf during the entire sighting. The reason to exclude the other groups was to avoid confusion in groups of several individuals performing aerial activities simultaneously. We checked whether assumptions of normality and equal variance were met before performing statistical tests. The distribution of variables in groups for t-Tests and errors in groups for Analyses of Variances (ANOVA) were visually inspected and moderate deviations were tolerated given the robustness of these tests. Differences in variances between groups were tested using Levene tests and the size of the ratio between the highest and the smallest variance.
Groups: To test whether the distances where groups were observed varied with the group composition and the period of the season an ANOVA followed a Tukey honest significant difference (HSD) test were used for each variable.

We considered three periods of the season (initial, middle and final, Table 1) due to differences in migratory timing of sexes and reproductive status of the groups and their behavioral differences associated with each period (Morete et al. 2007b). As the number of individuals varies throughout the season and the years, we calculated the day when the number of individuals would be higher for each season using a segmented regression model for the number of individuals observed throughout the season and considered it as the center of the middle period (Gonçalves et al. 2018).

Movement parameters: To test whether there was a difference in parameter values between the two years we used t-Tests. To test whether the movement parameter values were influenced by group composition, the season period, behavioral state, and net course class, we used ANOVAs followed by Tukey honest significant difference (HSD) tests for each variable analyzed. For net course, we used a circular variance analysis, and to check if the movement of humpback whale groups presented circular uniformity throughout the study we used the Rayleigh's test (Zar 1974). Statistical analyses were run in R 3.0.2 (R Development Core Team) and in PAST 3.10 (Paleontological Statistics).

\section{Results}

\section{Research effort}

We monitored 125 humpback whale tracks with a total of 2240 positions during 67 days in the field. Minimum and maximum distances tracked were $0.21 \mathrm{~km}$ and $10.59 \mathrm{~km}$ respectively, with a mean tracked distance of $2.88 \pm 2.20 \mathrm{~km}$ per focal.

The total time of group tracking was $61.4 \mathrm{~h}$ for both years and varied throughout the season due to the lower number of whales observed and bad weather conditions in the initial period. Total tracking time was 10.3 $\mathrm{h}$ in the initial period, $25.7 \mathrm{~h}$ in the middle period and $25.4 \mathrm{~h}$ in the final period. Focal time ranged from $0.16 \mathrm{~h}$ to $1.93 \mathrm{~h}(\mathrm{x}=0.49 \pm 0.34 \mathrm{~h})$. The focal time for each group composition was: $2.5 \mathrm{~h}$ for solitary animals, $6.2 \mathrm{~h}$ for dyads, $17.3 \mathrm{~h}$ for multiple groups, $21.5 \mathrm{~h}$ for MOCs, $5.7 \mathrm{~h}$ for MOCE, and $8.2 \mathrm{~h}$ for MOCE/+ groups (Table 2).

\section{Groups}

The most frequently tracked group types were those with calves (60.80\%), followed by multiple groups $(19.20 \%)$, dyads $(12.80 \%)$ and solitary individuals (7.20\%). Within groups with calf, MOC represents $60.52 \%$, MOCE $22.37 \%$ and MOCE/ $17.11 \%$. A single group of 2 adults and 2 calves was observed but not considered for the analyses because it was not possible to distinguish which calf would be used for tracking.

Mean distance from the coast of groups without calf was significantly greater than for groups with a calf $(\mathrm{t}=-6.4417, \mathrm{df}=114.07, \mathrm{p}<0.001$, Table 3). Within groups with a calf, we found significant variation in the distances from the coast of the groups sighted $(\mathrm{F}=11.32, \mathrm{df}=73$, $\mathrm{p}<0.001$ ). Mean distance from the coast of MOC was significantly lower than MOCE $(\mathrm{p}<0.05)$ and MOCE/+ $(\mathrm{p}<0.001)$ groups, and no 
Table 1. Beginning and end dates of initial, middle and final periods considered for each year in the study in Serra Grande (Bahia state, Brazil). The middle period has 41 days.

\begin{tabular}{lccc}
\hline Year & Initial & Middle & Final \\
\hline 2014 & 11 July-2 August & 3 August-12 September & 13 September-31 October \\
2015 & 20 July-14 August & 15 August-24 September & 25 September-25 October \\
\hline
\end{tabular}

Table 2. Number of effort days and duration of the focal follows of groups along the periods of the season in the study area in Serra Grande (Bahia state, Brazil). Total duration of focal follows in hours and number in parentheses for each group type. $1 \mathrm{AD}=$ one adult, dyad $=$ two adults, multiple $=$ three or more adults, $\mathrm{MOC}=$ mother and calf, $\mathrm{MOCE}=$ mother and calf and one escort, $\mathrm{MOCE} /+=$ mother and calf and two or more escorts.

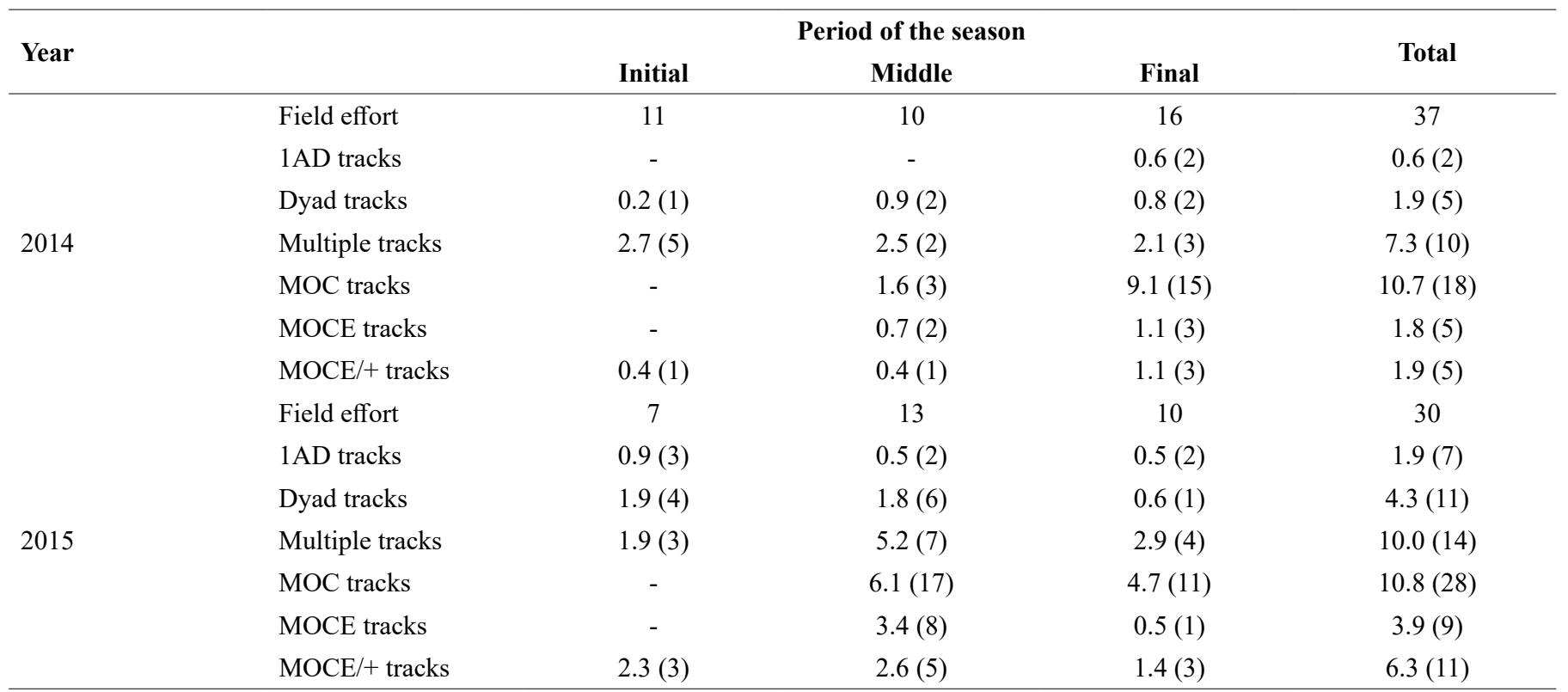

significant difference in distance from the coast was found between MOCE and MOCE/+ $(p=0.17$, Table 3$)$. We observed significant variation in the distances from the coast of the groups among periods of the season $(\mathrm{F}=21.25, \mathrm{df}=122, \mathrm{p}<0.001)$, with a decrease in distance as the season progressed (Table 3 ). There was a significant difference in group sighting distances from the coast between the initial and middle periods of the season $(p<0.001)$ and between the initial and final periods of the season $(p<0.001)$. However, there were no significant differences in the distance of groups from the coast between the middle and final periods of the season $(\mathrm{p}=0.35)$.

Table 3. Mean values and standard deviation of distances to coast $(\mathrm{km})$ where groups of humpback whales were initially observed from a land-based observation station in Serra Grande (Bahia state, Brazil) during 2014 and 2015: groups with calves and all groups between periods of the season. $\mathrm{MOC}=$ mother and calf, $\mathrm{MOCE}=$ mother and calf and one escort, $\mathrm{MOCE} /+=$ mother and calf and two or more escorts.

\begin{tabular}{lc}
\hline & Mean $( \pm$ SD) $\mathbf{k m}$ \\
\hline Without calf & $8.38( \pm 2.95)$ \\
With calf & $5.21( \pm 2.50)$ \\
MOC & $4.14( \pm 2.53)$ \\
MOCE & $6.07( \pm 3.30)$ \\
MOCE/+ & $7.84( \pm 1.75)$ \\
& \\
Initial period & $10.05( \pm 1.16)$ \\
Middle period & $6.12( \pm 3.14)$ \\
Final period & $5.37( \pm 2.76)$ \\
\hline
\end{tabular}

MOC groups spent more time resting (46.22\%) and MOCE and MOCE/+ swimming (66.46\% and $80.29 \%$ respectively). Time spent resting decreased with increasing numbers of escorts. Time spent swimming increased with increasing number of escorts (Figure 2).

\section{Movement parameters}

Leg and net speed: Mean leg speed of groups sighted in Serra Grande was $6.88 \pm 2.92 \mathrm{~km} / \mathrm{h}$ and mean net speed was $4.92 \pm 2.46 \mathrm{~km} / \mathrm{h}$ (Table 4). Net and leg speed showed a positive correlation $(\mathrm{r}=0.72$;

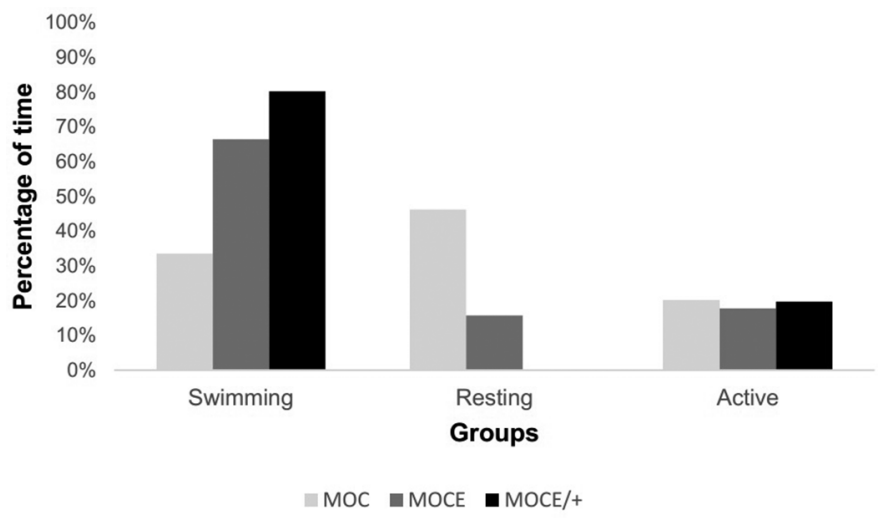

Figure 2. Percentage of time spent in the different behavioral states by humpback whale groups with a calf observed from a land-based observation station in Serra Grande (Bahia, Brazil) in 2014 and 2015. MOC = mother and calf, $\mathrm{MOCE}=$ mother and calf and one escort, $\mathrm{MOCE} /+=$ mother and calf and two or more escorts. 
$\mathrm{p}<0.001)$. Therefore, for the remaining analyses we used the leg speed only considering the full path travelled by the group to avoid underestimating the speed values. Leg speed and distance from the coast showed a positive correlation $(\mathrm{r}=0.51 ; \mathrm{p}<0.001)$, with an increase in leg speed with increasing distance from the coast. No difference in leg speed was found between years 2014 and $2015(\mathrm{t}=-0.79263, \mathrm{df}=68.834$, $\mathrm{p}=0.4307$ ).

We found significant differences in mean values of leg speed between group compositions $(\mathrm{F}=8.764, \mathrm{df}=104, \mathrm{p}<0.001$, Figure $3 \mathrm{a})$ : between MOC and MOCE/+ $(p<0.001)$, MOCE and MOCE/ $+(p<0.05)$, and MOC and multiple groups $(\mathrm{p}<0.001)$. Leg speed of groups with calf increased with increasing number of escorts (Figure $3 \mathrm{a}$ ). The decrease of leg speed across the periods of the season did not imply significant differences between them $(\mathrm{F}=2.438, \mathrm{df}=107, \mathrm{p}=0.092)$ or between net course classes $(\mathrm{F}=0.8447$, df $=107, \mathrm{p}=0.4326)$. Mean values of leg speed varied between behavioral states $(\mathrm{F}=10.16, \mathrm{df}=89, \mathrm{p}<0.001)$ with significantly lower values in resting groups than active $(\mathrm{p}<0.05)$ and swimming groups $(\mathrm{p}<0.001$, Figure $3 \mathrm{~b})$. Within groups with calf which were swimming, there was a significant difference in leg speed

Table 4. Descriptive statistics (mean, standard deviation, minimum, and maximum values) of movement parameters of humpback whale groups tracked from a land-based observation station in Serra Grande (Bahia state, Brazil) during 2014 and 2015.

\begin{tabular}{lcccc}
\hline & Mean & SD & Minimum & Maximum \\
\hline Net speed $(\mathrm{km} / \mathrm{h})$ & 4.92 & \pm 2.46 & 0.20 & 11.34 \\
Leg speed $(\mathrm{km} / \mathrm{h})$ & 6.88 & \pm 2.92 & 0.70 & 15.73 \\
Linearity & 0.81 & \pm 0.19 & 0.19 & 1.00 \\
Reorientation rate $(\% / \mathrm{min})$ & 25.72 & \pm 19.09 & 0.45 & 93.09 \\
Net course $\left({ }^{\circ}\right)$ & 178.22 & 65.34 & 2.48 & 359.59 \\
\hline
\end{tabular}

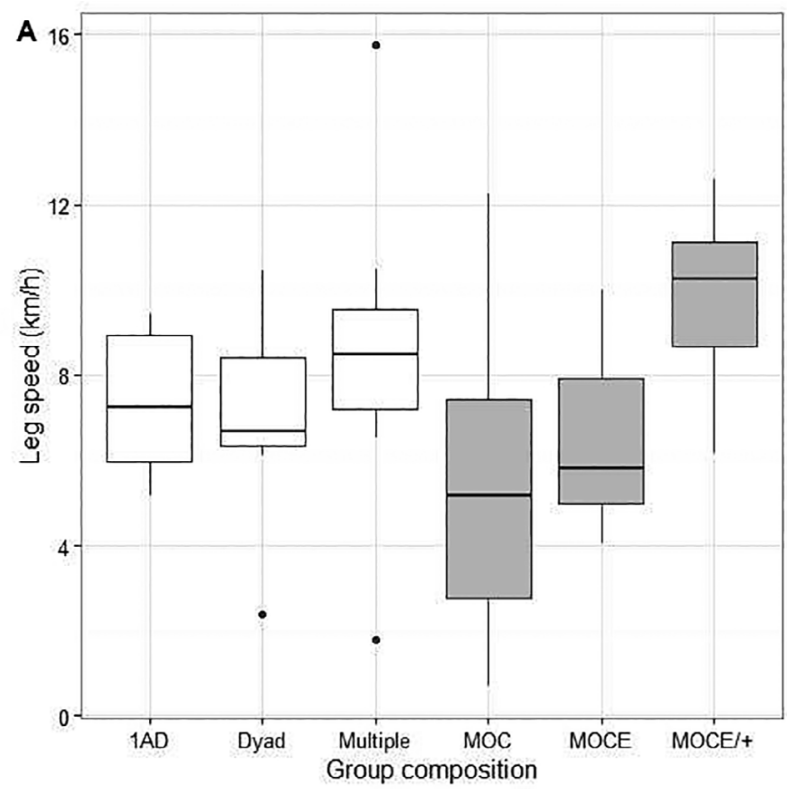

$(\mathrm{F}=9.357, \mathrm{df}=42, \mathrm{p}<0.001$, Table 5$):$ MOCE $/+$ moved significantly faster than MOC $(p<0.001)$ and than MOCE $(p<0.05)$. When resting, no difference was found in mean values of leg speed between MOC and MOCE groups $(\mathrm{F}=0.557, \mathrm{df}=22, \mathrm{p}=0.463$, Table 5).

Linearity: Linearity mean value of groups tracked was $0.81 \pm 0.19$ (Table 4 ) and $69.09 \%$ of humpback whale tracks showed values above 0.80 . No significant difference was found between years $(\mathrm{t}=0.3466$, $\mathrm{df}=78.581, \mathrm{p}=0.7298)$ nor between group composition $(\mathrm{F}=0.6478$. $\mathrm{df}=104, \mathrm{p}=0.6638)$. Linearity values varied $(\mathrm{F}=6.44, \mathrm{df}=107, \mathrm{p}<0.05)$ and increased during periods of the season (Figure $4 \mathrm{a}$ ): being significantly lower in the initial period than in final period $(\mathrm{p}<0.05)$. There was a greater linearity variation in the initial and middle periods than in the final (Figure 4a). No significant difference was found between behavioral states $(\mathrm{F}=1.031, \mathrm{df}=89, \mathrm{p}=0.3608)$. Linearity values showed a significant difference depending on net course classes $(\mathrm{F}=14.87, \mathrm{df}=107$, $\mathrm{p}<0.001)$ between south and north $(\mathrm{p}<0.05)$ and between south and other directions $(\mathrm{p}<0.001)$. Groups moving south presented more linear trajectories $(\mathrm{x}=0.87 \pm 0.13)$ than groups moving to north $(\mathrm{x}=0.73 \pm 0.25)$ and towards another direction $(x=0.62 \pm 0.21$, Figure 5).
Table 5. Mean and standard deviation values of leg speed $(\mathrm{km} / \mathrm{h})$ of mother and calf groups in swimming and resting behavior observed from a land-based observation station in Serra Grande (Bahia state, Brazil) during 2014 and 2015. $\mathrm{MOC}=$ mother and calf, $\mathrm{MOCE}=$ mother and calf and one escort, $\mathrm{MOCE} /+=$ mother and calf and two or more escorts.

\begin{tabular}{lcc}
\hline & Swimming & Resting \\
\hline MOC & $6.21( \pm 2.58)$ & $3.69( \pm 2.37)$ \\
MOCE & $6.88( \pm 2.22)$ & $4.62( \pm 1.46)$ \\
MOCE/+ & $9.81( \pm 2.04)$ & - \\
\hline
\end{tabular}

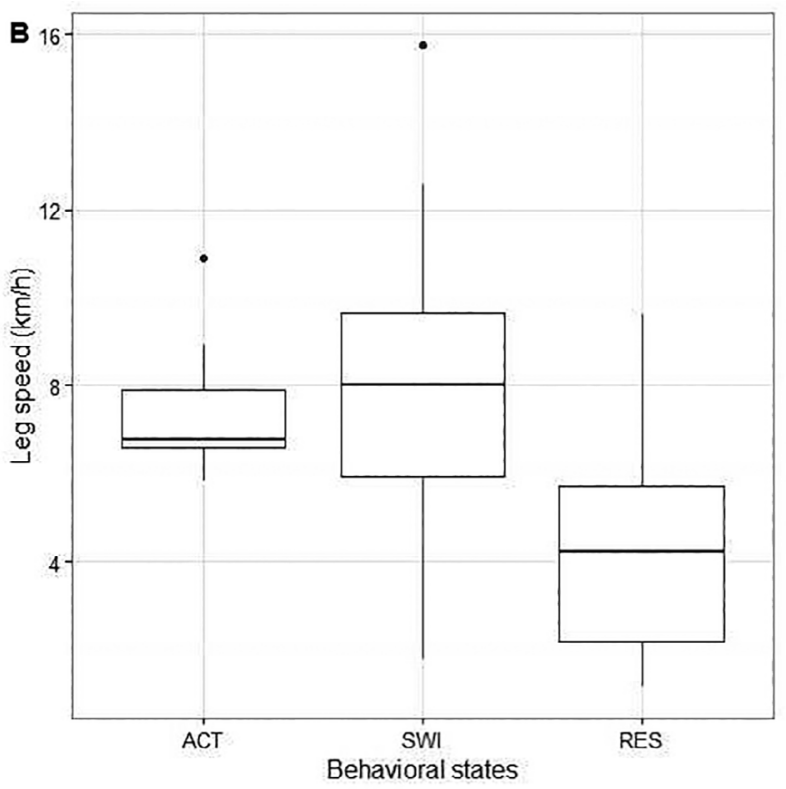

Figure 3. Box plot of leg speed among group composition (A) and among behavioral states (B) of humpback whale groups sighted from a land-based observation station in Serra Grande (Bahia, Brazil) in 2014 and 2015. 1AD = solitary individual, Dyad = two adults, Multiple $=$ three or more adults, $\mathrm{MOC}=$ mother and calf, $\mathrm{MOCE}=$ mother and calf and one adult, $\mathrm{MOCE} /+=$ mother and calf and two or more adults . ACT $=$ active groups, SWI = swimming groups, RES = resting groups. The minimum and maximum values are represented at the extremities, the center line represents the median, the bottom line of the box is the first quartile and the upper line is the third quartile. 

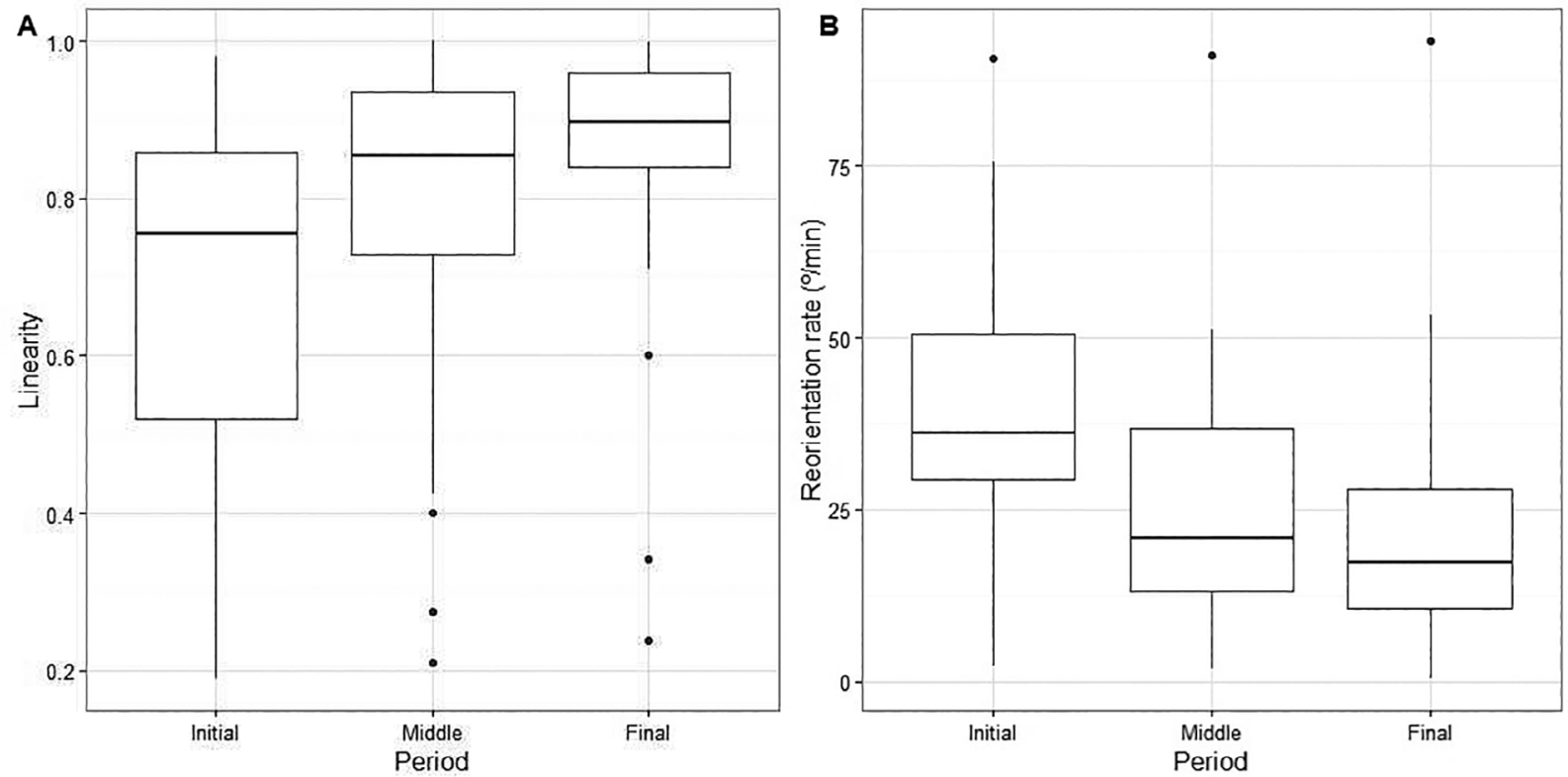

Figure 4. Boxplot of linearity (A) and of reorientation rate (B) of humpback whale groups observed from a land-based observation station in Serra Grande (Bahia state, Brazil) in 2014 and 2015 between periods of the season. The minimum and maximum values are represented at the extremities, the center line represents the median, the bottom line of the box is the first quartile and the upper line is the third quartile.

Reorientation rate: The mean reorientation rate was $25.72 \pm 19.09$ $\%$ min (Table 4). There was no significant difference between reorientation rates between 2014 and $2015(\mathrm{t}=-0.4145, \mathrm{df}=81.524$, $\mathrm{p}=0.6796)$ or among group composition $(\mathrm{F}=0.641, \mathrm{df}=104, \mathrm{p}=0.0669)$. Reorientation rate varied significantly between periods of the season $(F=6.71, d f=107, p<0.05)$, being higher in the initial period of the season than in the final period $(p<0.05$, Figure $4 b)$. Reorientation rate did not change with behavioral state $(\mathrm{F}=0.1443, \mathrm{df}=89, \mathrm{p}=0.8658)$ nor within classes of net course $(\mathrm{F}=2.682, \mathrm{df}=107, \mathrm{p}=0.073)$.

Net course: The mean value of net course of observed groups in Serra Grande was $178.22 \pm 65.34^{\circ}$ (Table 4). The null hypothesis for uniformity of movement of the groups was rejected (Rayleigh's $\mathrm{R}=65.277$, Rayleigh's $\mathrm{Z}=34.054, \mathrm{r}=0.522, \mathrm{p}<0.001$ ) with south direction predominating (Figure 6) throughout the season (Figure 7). We did not find significant difference in mean values of net course between the years $(\mathrm{F}=0.065, \mathrm{df}=1, \mathrm{p}=0.799)$, among group compositions $(\mathrm{F}=0.7204, \mathrm{df}=5, \mathrm{p}=0.7204)$, behavioral states $(\mathrm{F}=1.6782, \mathrm{df}=2$, $\mathrm{p}=0.5101)$ or season periods $(\mathrm{F}=0.9558, \mathrm{df}=2, \mathrm{p}=0.3873)$.

\section{Discussion}

Movement patterns and information about behavioral states of humpback whales in the Brazilian wintering ground are poorly known and required to understand habitat use off Brazil (Zerbini et al. 2006; Bortolotto et al. 2017). This study showed that the movement of the groups from BSA that were observed in Serra Grande, representing similar geomorphological characteristics with the Brazilian coast northern of Abrolhos, are influenced by the orientation of the coast which guides most trajectories parallel to it. Our hypothesis of the influence of spatio-temporal and behavioral aspects on the movement patterns was supported by our results.

Most groups were sighted heading south, and as one of the limitations of studies performed through land-based stations is the geographic range of the study area (Morete et al. 2017), most whales moving north maybe were not sampled during our effort. This may be a result of variation in habitat use in this area, with whales moving north using offshore waters, out of our monitoring range, as suggested in a previous work (Gonçalves et al. 2018). Humpback whale's sightings in July and August off Trindade Island (approximately $1100 \mathrm{~km}$ away from the coast) (Siciliano et al. 2012) support the hypothesis that groups moving northward early in the season could travel further offshore as also observed in Australia (Jenner et al. 2001). Another explanation for the low number of groups heading north could be that they are moving north before July, but because the visual surveys were only initiated in July and the weather conditions were not always ideal, this might have affected the number of observed groups towards that direction. However, whales moving south seem to follow the coastline more closely.

Humpback whales may use the South Equatorial Current Bifurcation which reaches approximately $17^{\circ} \mathrm{S}$ in July (Rodrigues et al. 2007) to travel closer to the Brazilian coast. Whales might be taking advantage of the predominant current in the region to save energy. The North Brazil Undercurrent flows north until July and is stronger further away from shore (Rezende et al. 2011). From August, the Brazilian Current predominates (Rezende et al. 2011) and it could help the whales going south. The net course of whale groups in oceanic habitats in Madagascar is influenced by the prevailing currents (Trudelle et al. 2016). Studies in larger spatial scales are needed from whales travelling from Southern feeding grounds towards the Brazilian coast, helping to understand their preferred routes.

We observed a decrease in the distance to the coast of the groups as the season progressed which should be justified by the increase in the number of calves throughout the season, which remain closer to the coast. Segregation of groups with calves close to shore in shallower waters in Serra Grande is consistent with the findings from other breeding areas (Smultea 1994; Ersts \& Rosenbaum 2003; Guidino et al. 2014). The increase in distance from the coast of the groups 


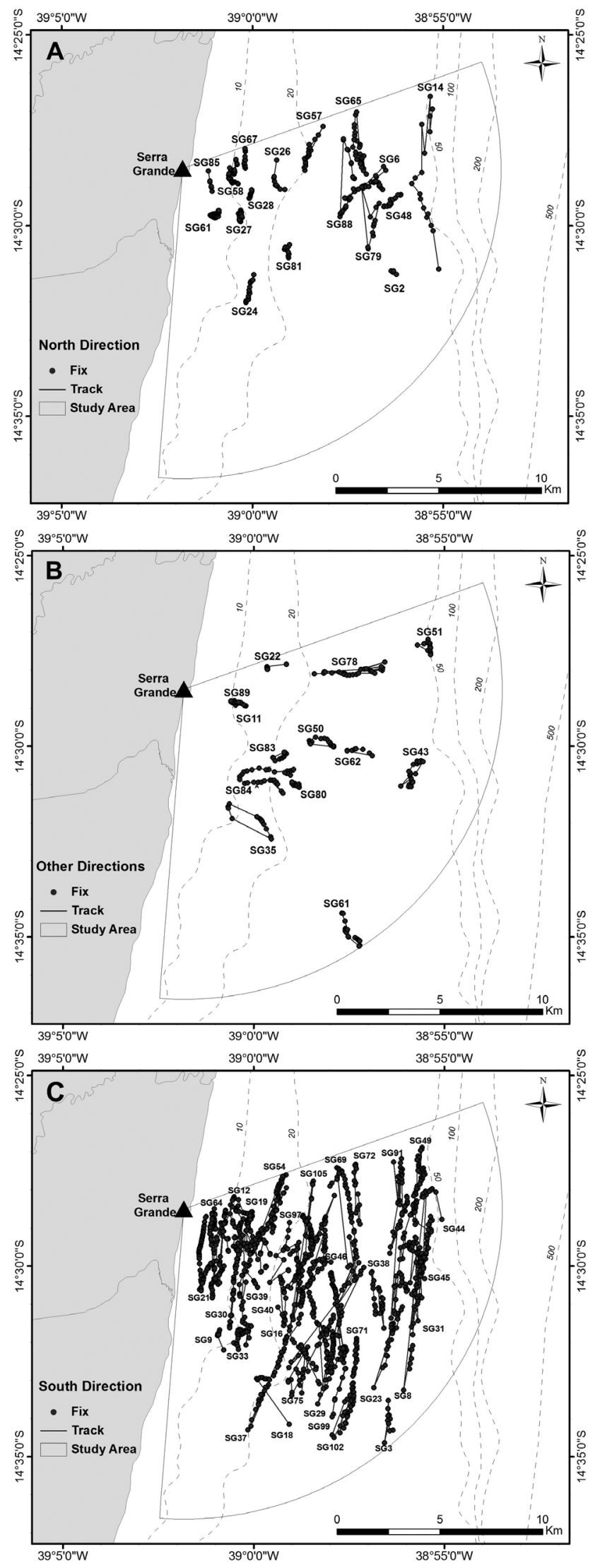

Figure 5. Tracks of humpback whale groups sighted from a land-based observation station in Serra Grande (Bahia state, Brazil) in 2014 and 2015 by the different classes of net course. North $=$ from $320^{\circ}$ to $50^{\circ}(\mathrm{A})$, Other directions $=$ between $50^{\circ}$ and $140^{\circ}$ and between $230^{\circ}$ and $320^{\circ}(\mathrm{B})$, South $=$ from $140^{\circ}$ to $230^{\circ}(\mathrm{C})$. 


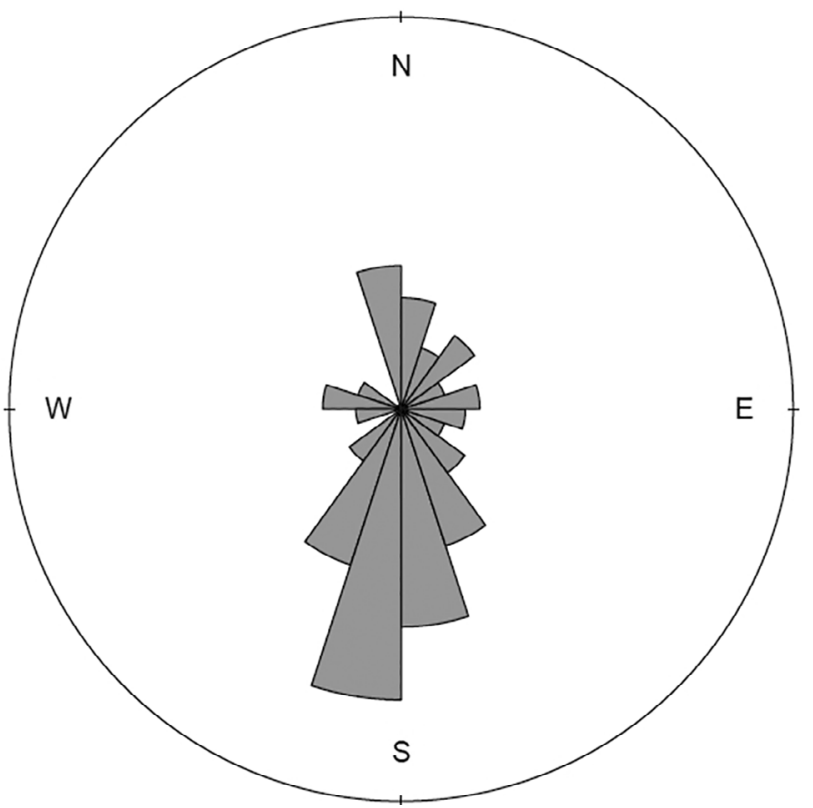

Figure 6. Frequencies of net course followed by humpback whale groups sighted from a land-based observation station in Serra Grande (Bahia, Brazil) in 2014 and 2015.

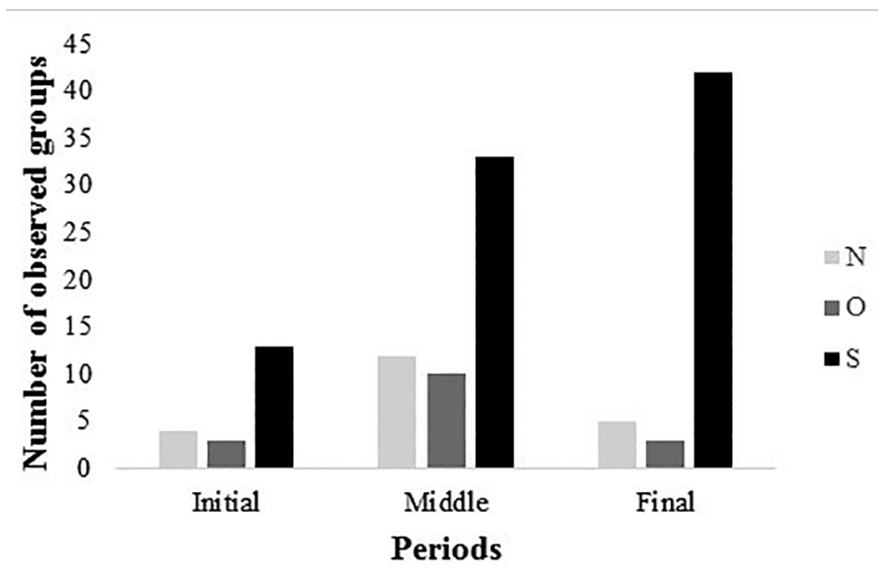

Figure 7. Frequencies of number of humpback whale groups observed from a land-based observation station in Serra Grande (Bahia, Brazil) among the periods of the season (initial, middle and final) by the different classes of net course. $\mathrm{N}=$ from $320^{\circ}$ to $50^{\circ}, \mathrm{O}=$ between $50^{\circ}$ and $140^{\circ}$ and between $230^{\circ}$ and $320^{\circ}, \mathrm{S}=$ from $140^{\circ}$ to $230^{\circ}$.

with calves with increasing number of escorts was also observed by Félix \& Botero-Acosta (2011) in Ecuador and by Craig et al. (2014) in Hawaii using two different platforms of observation, opportunistic boat sightings and from a land-based station, respectively. Concentration of mothers with calves in shallower waters may be a strategy to avoid male harassment, maternal care disturbance, and calf injury during male courting behavior (Smultea 1994; Ersts \& Rosenbaum 2003; Craig et al. 2014). Calves spent a long time in sucking behavior, so mother and calf groups become more vulnerable to disturbance, and it is advantageous to stay in calmer waters (Videsen et al. 2017). Zoidis \& Lomac-MacNair (2017) registered interruption of lactation in the presence of an escort. Pack et al. (2017) also observed that mothers adjust their habitat preferences according to calves age and grow in
Hawaiian breeding grounds. Mother and calf groups stayed closer to shore when the calves are younger, presenting a gradual movement to deeper water with the maturation of the calves, maybe preparing them to migration (Pack et al. 2017).

The number of escorts of a mother and calf group, besides increasing their distance from the coastline, also resulted in an increase movement speed. Faster movements can lead to an increase in energy expenditure (Craig et al. 2014) for both mother and calf, and maybe a decrease in the growth rate of the calf (Braithwaite et al. 2015). In fact, we found the same general pattern of increased speeds with greater distance from shore for all group compositions as observed in Madagascar (Trudelle et al. 2016). Cartwright \& Sullivan (2009) found that, despite the increase of speed related to the number of escorts, there was no significant difference in movement patterns between MOC and MOCE groups, and the same pattern was observed in Serra Grande. Those authors suggested that females choose to have a single male escort close by, as proposed by the bodyguard hypothesis (Mesnick 1996). A single escort may protect females with calves from harassment by other males when the mother-calf pair becomes more vulnerable in open waters further away from the coast (Cartwright \& Sullivan 2009).

Two factors contributing to energy expenditure in humpback whales are the mean movement speed and the time spent in resting versus swimming (Braithwaite et al. 2015). Our data suggest that time spent resting behavior by MOCE compared to MOC groups was reduced to less than half, and it was not observed in MOCE/+. The opposite was observed in time spent swimming, which doubles for mothers and calves that are escorted by one male and becomes the dominant activity of $\mathrm{MOCE} /+$ groups. Additionally, resting is a strategy that benefits the mother-calf pair allowing more time for nursing (Braithwaite et al. 2015). Therefore, mother and calf groups seem to adjust their movement patterns in response to social factors, such as the presence of escorts.

The mean leg speed of $6.88 \mathrm{~km} / \mathrm{h}$ observed in Serra Grande was higher compared to other studies conducted from land-based stations. The mean leg speeds off the migratory corridor in west coast of Africa was $4.6 \mathrm{~km} / \mathrm{h}$ (Barendse et al. 2010), and during the Southern migration on the east coast of Australia was $4.7 \mathrm{~km} / \mathrm{h}$ (Burns 2010). Differences in local current speeds could be one of the reasons to explain those differences. The highest current speed in the area can reach $3.6 \mathrm{~km} / \mathrm{h}$ with the mean value of $0.72 \mathrm{~km} / \mathrm{h}$ (BAMIN 2011), being one of the possible reasons for the high-speed value observed, as for example of the groups in resting behavior, that could be drifting with the current. Nevertheless, the mean net speed obtained in our study was close to that found from other breeding areas (Frankel et al. 1995; Findlay et al. 2011) but higher than the ones registered in an area next to a sheltered bay, with possibly quieter waters (Barendse et al. 2010) than Serra Grande, which is an open ocean area. Environmental variables may influence the behavior of humpback whales (Kavanagh et al. 2016), and more protected waters could allow moving at lower speeds. During satellite-monitoring studies of humpback whales of BSA, Horton et al. (2017) reported speeds between 4.3 and $5.0 \mathrm{~km} / \mathrm{h}$ during south-directed movements. Speed data may show variation depending on how they were obtained (Findlay et al. 2011), using land-based surveys or satellite telemetry, with more detailed data being obtained from land platforms. For example, Chittleborough (1953) reported a mean speed of $8.0 \mathrm{~km} / \mathrm{h}$ during aerial surveys in Australia on short-term observations during migration. 
As observed by Dalla Rosa et al. (2008), speed was dependent on the behavioral state. However, no variation in the reorientation rate and linearity was observed among behavioral states: whales in swimming behavior did not show more directional paths as initially expected. Travelling individuals could follow more direct paths than individuals resting or searching for mates, but this was not observed. Nevertheless, reorientation rate and linearity were influenced by the period of the season. Groups at the beginning of the season had more erratic movements and as the season progressed they were gradually showing more linear movements, which may be related to the approaching migration to feeding areas. We found that the groups going south showed higher linearity than other groups. Groups with less linear paths might be still searching for a mate or may be pregnant females arriving to give birth at the calving grounds. However, despite the differences in linearity, no differences were found in the speed of groups moving north or south. Individuals may maintain a similar speed regardless of the direction they follow, for example, while they are in the breeding area, some individuals may be trying to mate, and mothers may take advantage of the time before the migratory period to feed and nurse their calves.

The mean linearity value obtained here suggests limited straight movement in the study area (Barendse et al. 2010), which highlights that in spite of Serra Grande is in a low-density area (Andriolo et al. 2010), the humpback whales do not use it only as a travelling corridor. The erratic movements and the high percentage of groups with calves in resting behavior reinforce the idea that the area is a calving ground (Gonçalves et al. 2018), where mother and calves stay to nurse, and is indeed reoccupying areas previously affected by whaling (Rossi-Santos et al. 2008). The linearity values were similar to those observed in other breeding areas (Schaffar et al. 2009), lower than in migratory areas (Burns 2010) but higher than observed in some feeding areas (Stanistreet et al. 2013). Groups of humpback whales in Serra Grande showed erratic movements with great change of direction per minute and reorientation rates higher than other breeding areas such as at the calm waters of New Caledonia (Schaffar et al. 2009). There were no differences in the reorientation rate between group composition. In contrast, Noad $\&$ Cato (2007) reported that groups with calves in Australia changed direction more often during migration. Linearity patterns of groups with calves in Serra Grande were similar to those observed in the Abrolhos Bank (Bisi 2006). However, the higher speed observed for groups with calves in Serra Grande could be due to less shallow and protected waters compared to the Abrolhos Bank.

Movement patterns of humpback whales can vary between breeding and feeding areas and migratory corridors (Lagerquist et al. 2008). These patterns can also vary within breeding areas, where humpback whales can adjust their behavior depending on the characteristics of the area and energy demands. Serra Grande is an area that is used during the breeding season by mothers with calves to rest. Consequently, with the increase of the population (Bortolotto et al. 2016; Pavanato et al. 2017) and extension of the breeding areas, special attention should be given to the planned human activities in the region, such as the construction of a new offshore port approximately $10 \mathrm{~km}$ from the study area (BAMIN 2011). Anthropogenic activities may impact humpback whales because of the lack of reinforcement of protected measures. Resting areas are particularly sensitive to disturbance because the interruption of resting behavior may lead to decreased lactation time and growth of calves (Braithwaite et al. 2015). Monitoring any changes in movement patterns, such as an increase in reorientation rate to avoid vessels and/or adoption of more linear paths and higher speeds to move away from the region would raise concerns about the potential impacts on the humpback whales in the Serra Grande region.

\section{Acknowledgments}

We want to thank the field assistants Erica Lopes, Evelyn Fróes, Juliede Nonato, Luana Pini, Mariana Campêlo, Stella Tomás, Winnie Silva and the logistic support at the land-based observation station from Giulio Lombardi, Davi Santiago, Mr. Nelson Cangirana and Mr. Raimundo Gomes. Special thanks to Maria Morete for the invitation for the field work with the land-based observation study in Abrolhos, and to Cristiane Martins for reviewing the spreadsheet of parameters calculations and the text. We are grateful to Harildon Ferreira by providing the maps of the paper. We would like to thank Aldo Pacheco, Artur Andriolo, Jorge Acevedo, Luciano Dalla Rosa, Trish Franklin, Yvonnick Le Pendu and the anonymous reviewers for the valuable comments in the text. This work was supported by the Universidade Estadual de Santa Cruz (UESC) and by Cetacean Society International (CSI). We thank the Coordination for the Improvement of Higher Education Personnel (CAPES) for the Ph.D. scholarship granted to M.I.C.G. G.H.C. received financial support from the São Paulo Research Foundation (FAPESP \#14292-9).

\section{Author Contributions}

Maria Isabel Carvalho Gonçalves: Substantial contribution in the concept and design of the study; Contribution to data collection; Contribution to manuscript preparation; Contribution to critical revision, adding intelectual content.

Renata Santoro de Sousa-Lima: Contribution to data analysis and interpretation; Contribution to manuscript preparation; Contribution to critical revision, adding intelectual content.

Niel Nascimento Teixeira: Contribution to data collection; Contribution to data analysis and interpretation; Contribution to manuscript preparation; Contribution to critical revision, adding intelectual content.

Gustavo Henrique Carvalho: Contribution to data analysis and interpretation; Contribution to manuscript preparation; Contribution to critical revision, adding intelectual content.

Daniel Danilewicz: Contribution to data collection; Contribution to manuscript preparation; Contribution to critical revision, adding intelectual content.

Júlio Ernesto Baumgarten: Contribution to data analysis and interpretation; Contribution to manuscript preparation; Contribution to critical revision, adding intelectual content.

\section{Conflicts of interest}

The authors declare that they have no conflict of interest related to the publication of this manuscript. 


\section{References}

AMORIM, F.N., CIRANO, M., SOARES, I.D. \& LENTINI, C.A. D. 2011 Coastal and shelf circulation in the vicinity of Camamu Bay $\left(14^{\circ} \mathrm{S}\right)$, Eastern Brazilian. Shelf. Cont. Shelf. Res. 31:108-119.

ANDriolo, A., KINAS, P.G., ENGEL, M.H., MARTINS, C.C.A. \& RUFINO, A.M. 2010. Humpback whales within the Brazilian breeding ground: distribution and population size estimate. Endanger. Species Res. 11:233-243.

BAILEY, H. \& THOMPSON, P. 2006. Quantitative analysis of bottlenose dolphin movement patterns and their relationship with foraging. J. Anim. Ecol. 75(2):456-465.

BAMIN. 2011. Relatório de Impacto Ambiental Porto Sul. Bahia Mineração Ltda.

BARENDSE, J., BEST, P.B., THORNTON, M., POMILLA, C., CARVALHO I. \& ROSENBAUM, H.C. 2010. Migration redefined? Seasonality, movements and group composition of humpback whales Megaptera novaeangliae off the west coast of South Africa. Afr. J. Mar. Sci. 32(1):1-22.

BEST, P.B., SEKIGUCHI, S. \& FINDLAY, K.P. 1995. A suspended migration of humpback whales Megaptera novaeangliae on the west coast of South Africa. Mar. Eco-Prog. Ser. 118:1-12.

BISI, T. L. 2006. Comportamento de filhotes de baleia jubarte, Megaptera novaeangliae, na região ao redor do Arquipélago dos Abrolhos, Bahia (Brasil). Dissertação de mestrado, Universidade de São Paulo, São Paulo.

BORTOLOTTO, G.A., DANILEWICZ, D., ANDRIOLO, A., SECCHI, E.R \& ZERBINI, A.N. 2016. Whale, Whale, Everywhere: Increasing Abundance of Western South Atlantic Humpback Whales (Megaptera novaeangliae) in Their Wintering Grounds. PLoS ONE. 11(10):e0164596.

BORTOLOTTO, G.A., DANILEWICZ, D., HAMMOND, P.S., THOMAS, L. \& ZERBINI, A.N. 2017. Whale distribution in a breeding area: spatial models of habitat use and abundance of western South Atlantic humpback whales. Mar. Eco-Prog. Ser. 585:213-227.

BRAITHWAITE, J.E., MEEUWIG, J.J. \& HIPSEY, M.R. 2015. Optimal migration energetics of humpback whales and the implications of disturbance. Conserv. Physiol. 3:cov001.

BURNS, D. 2010. Population characteristics and migratory movements of humpback whales (Megaptera novaeangliae) identified on their southern migration past Ballina, eastern Australia. PhD Thesis, Southern Cross University, Lismore.

CARTWRIGHT, R., GILlESPIE, B., LABONTE, K., MANGOLD, T., VENEMA, A., EDEN, K. \& SULLIVAN, M. 2012. Between a Rock and a Hard Place: Habitat Selection in Female-Calf Humpback Whale (Megaptera novaeangliae) Pairs on the Hawaiian Breeding Grounds. PLoS ONE. 7(5):e38004.

CARTWRIGHT, R. \& SULLIVAN, M. 2009. Associations with multiple male groups increase the energy expenditure of humpback whale (Megaptera novaeangliae) female and calf pairs on the breeding grounds. Behaviour. 146:1573-1600.

CHITTLEBOROUGH, R.G. 1953. Aerial observations on the Humpback whale, Megaptera nodosa (Bonnaterre), with notes on other species. Aust. J. Mar Freshw. Res. 4(2):219-227.

CLAPHAM, P.J. 2000. The Humpback Whale: Seasonal Feeding and Breeding in a Baleen Whale. In Cetacean Societies: Field Studies of Dolphins and Whales (J. Mann, R.C. Connor, P.L. Tyack \& H. Whitehead, eds.). The University of Chicago Press, Chicago, pp. 173-196.

CLAPHAM, P.J. 2009. Humpback Whale. In Encyclopedia of Marine Mammals (W.F.Perrin, B. Würsig \& J.G.M. Thewissen, eds.). Academic Press, San Diego, pp. 582-585.

CORKERON, P.J. \& CONNOR, R.C. 1999. Why do baleen whales migrate? Mar. Mammal Sci. 15(4):1228-1245.

CRAIG, A.S., HERMAN, L.M., PACK, A.A. \& WATERMAN, J.O. 2014. Habitat segregation by female humpback whales in Hawaiian waters: avoidance of males? Behaviour. 151:613-631.
DALLA ROSA, L., SECCHI, E.R., MAIA, Y.G., ZERBINI, A.N. \& HEIDEJØRGENSEN, M.P. 2008. Movements of satellite-monitored humpback whales on their feeding ground along the Antarctic Peninsula. Polar. Biol. 31(7):771-781.

DANILEWICZ, D., MORENO, I.B., TAVARES, M. \& SUCUNZA, F. 2016 Southern right whales (Eubalaena australis) off Torres, Brazil: group characteristics, movements, and insights into the role of the BrazilianUruguayan wintering ground. Mammalia. 81:1864-1547.

DAWBIN, W.H. 1956. The Migrations of Humpback Whales which Pass The New Zealand Coast. T. Roy. Soc. NZ. 84(1):147-196.

DAWBIN, W.H. 1966. The seasonal migratory cycle of humpback whales. In Whales, dolphins, and porpoises (K.S. Norris, ed.). University of California Press, Berkeley, pp. 145-170.

ENGEL, M.H. \& MARTIN, A.R. 2009. Feeding grounds of the western South Atlantic humpback whale population. Mar. Mammal Sci. 25:964-969.

ERSTS, P.J. \& ROSENBAUM, H.C. 2003. Habitat preference reflects social organization of humpback whales (Megaptera novaeangliae) on a wintering ground. J. Zoo. 260:337-345.

FÉLIX, F. \& BOTERO-ACOSTA, N. 2011. Distribution and behaviour of humpback whale mother-calf pairs during the breeding season off Ecuador. Mar. Eco-Prog. Ser. 426:277-287.

FINDLAY, K.P. \& BEST, P.B. 1996. Estimates of the numbers of humpback whales observed migrating past Cape Vidal, South Africa, 1988-1991. Mar. Mammal Sci. 12(3):354-370.

FINDLAY, K.P., BEST, P.B. \& MEŸER, M.A. 2011. Migrations of humpback whales past Cape Vidal, South Africa, and an estimate of the population increase rate (1988-2002). Afr. J. Mar. Sci. 33(3):375-392.

FRANKEL, A.S., CLARK, C.W., HERMAN, L.M. \& GABRIELE, C.M. 1995. Spatial distribution, habitat utilization, and social interactions of humpback whales, Megaptera novaeangliae, off Hawai's, determined using acoustic and visual techniques. Can. J. Zool. 73:1134-1146.

GAILEY, G. \& ORTEGA-ORTIZ, J.G. 2002. A note on a computer-based system for theodolite tracking of cetaceans. J. Cetacean Res. Manage. 4(2):213-218.

GAILEY, G., WÜRSIG, B. \& MCDONALD, T.L. 2007. Abundance, behavior, and movement patterns of western gray whales in relation to a 3-D seismic survey, Northeast Sakhalin Island, Russia. Environ. Monit Assess. 134:75-91.

GODWIN, E.M., NOAD, M.J., KNIEST, E. \& DUNLOP, R.A. 2016. Comparing multiple sampling platforms for measuring the behavior of humpback whales (Megaptera novaeangliae). Mar. Mammal Sci. 32(1):268-286.

GONÇALVES, M.I.C. 2017. Uso de habitat, comportamento e emissões acústicas das baleias-jubarte (Megaptera novaeangliae) na região de Serra Grande - Bahia. Tese de doutorado, Universidade Estadual de Santa Cruz, Ilhéus.

GONÇALVES, M.I.C., SOUSA-LIMA, R.S., TEIXEIRA, N.N., MORETE, M.E., CARVALHO, G.H., FERREIRA, H.M. \& BAUMGARTEN, J.E. 2018. Low latitude habitat use patterns of a recovering population of humpback whales. J. Mar. Biol. Assoc. UK. 1-10.

GUIDINO, C., LLAPAPASCA, M.A., SILVA, S., ALCORTA, B. \& PACHECO, A. S. 2014. Patterns of Spatial and Temporal Distribution of Humpback Whales at the Southern Limit of the Southeast Pacific Breeding Area. PLoS ONE. 9(11):e112627.

HERMAN, L.M. 1979. Humpback Whales in Hawaiian Waters: A Study in Historical Ecology. Pac. Sci. 33(1):1-15.

HORTON, T.W., HAUSER, N., ZERBINI, A.N., FRANCIS, M.P., DOMEIER, M.L., ANDRIOLO, A., COSTA, D.P., ROBINSON, P.W., DUFFY, C.A.J., NASBY-LUCAS, N., HOLDAWAY, R.N. \& CLAPHAM, P.J. 2017. Route Fidelity during Marine Megafauna Migration. Front. Mar. Sci. 4:422. 
HORTON, T.W., HOLDAWAY, R.N., ZERBINI, A.N., HAUSER, N., GARRIGUE, C., ANDRIOLO, A. \& CLAPHAM, P.J. Straight as an arrow: humpback whales swim constant course tracks during long-distance migration. Biol. Letters. 7:674-679.

IBGE. 2011. Atlas geográfico das zonas costeiras e oceânicas do Brasil, Rio de Janeiro.

IWC. 2005. Report of the Scientific Committee. Annex H - Report of the subcommittee on other southern hemisphere whale stocks. J. Cetacean Res. Manage. 7(Suppl.):235-246.

JENNER, K.C.S., JENNER, M.-N.M. \& MCCABE, K.A. 2001. Geographical and temporal movements of humpback whales in Western Australian waters. APPEA. 41(1):749-765.

KAVANAGH, A.S., NOAD, M.J., BLOMBERG, S.P., GOLDIZEN, A.W., KNIEST, E., CATO, D.H. \& DUNLOP, R.A. 2016. Factors driving the variability in diving and movement behavior of migrating humpback whales (Megaptera novaeangliae): Implications for anthropogenic disturbance studies. Mar. Mammal Sci. 33(2): 413-439.

KENNEDY, A.S., ZERBINI, A.N., VÁSQUEZ, O.V., GANDILHON, N., CLAPHAM, P.J. \& ADAM, O. 2014. Local and migratory movements of humpback whales (Megaptera novaeangliae) satellite-tracked in the North Atlantic Ocean. Can. J. Zool. 92:9-18.

LAGERQUIST, B.A., MATE, B.R., ORTEGA-ORTIZ, J. G., WINSOR, M. \& URBÁN-RAMIREZ J. 2008. Migratory movements and surfacing rates of humpback whales (Megaptera novaeangliae) satellite tagged at Socorro Island, Mexico. Mar. Mammal Sci. 24(4):815-830.

MANN, J. 1999. Behavioral sampling methods for cetaceans: a review and critique. Mar. Mammal Sci. 15(1):102-122.

MARTINS, C.C.A. 2012. Study of Baleen Whales' Ecology and Interaction with Maritime Traffic Activities to Support Management of a Complex Socio-Ecological System. PhD Thesis, Université de Montréal, Montréal.

MARTINS, C.C.A., MORETE, M.E., ENGEL, M.H., FREITAS, A.C., SECCHI, E.R. \& KINAS, P.G. 2001. Aspects of habitat use patterns of humpback whales in the Abrolhos Bank, Brazil, breeding ground. Mem. Queensl. Mus. 27(2):563-570.

MESNICK, S.L. 1996. Sexual selection and biological diversification: Patterns and processes. $\mathrm{PhD}$ Thesis, University of Arizona, Tucson.

MIKHALEV, Y.A. 1997. Humpback whales Megaptera novaeangliae in the Arabian Sea. Mar. Eco-Prog. Ser. 149: 13-21.

MONICO, J.F.G. 2008. Posicionamento pelo GNSS - descrição, fundamentos e aplicações. UNESP, São Paulo.

MORETE, M.E. 2007. Caracterização temporal da estrutura de grupos e do comportamento de baleias jubarte na área de reprodução da região do Arquipélago dos Abrolhos (Bahia, Brasil). Tese de doutorado, Universidade de São Paulo, São Paulo.

MORETE, M.E., ABRAS, D. \& MARTINS, C.C.A. 2017. Land-Based Studies of Aquatic Mammals in Latin America: Understanding Behavior for Conservation. In Advances in Marine Vertebrate Research in Latin America. Technological Innovation and Conservation (M.R. Rossi-Santos \& C.W. Finkl, eds.). SPRINGER, pp. 77-112.

MORETE, M.E., BISI, T.L., PACE, R.M. \& ROSSO, S. 2008. Fluctuating abundance of humpback whales (Megaptera novaeangliae) in a calving ground off coastal Brazil. J. Mar. Biol. Assoc. UK. 88:1229-1235.

MORETE, M.E., BISI, T.L. \& ROSSO, S. 2007a. Mother and calf humpback whale responses to vessels around the Abrolhos Archipelago, Bahia, Brazil. J. Cetacean Res. Manage. 9(3):241-248.

MORETE, M.E., BISI, T.L. \& ROSSO, S. 2007b. Temporal pattern of humpback whale (Megaptera novaeangliae) group structure around Abrolhos Archipelago breeding region, Bahia, Brazil. J. Mar. Biol. Assoc. UK. 87:87-92.

Morete, M.E., FreitAs, A.C., ENGEL, M.H., PACE, R.M. \& CLAPHAM, P.J. 2003. A novel behavior observed in humpback whales on wintering grounds at Abrolhos Bank (Brazil). Mar. Mammal Sci. 19:694-707.
NOAD, M.J. \& CATO, D.H. 2007. Swimming speeds of singing and nonsinging humpback whales during migration. Mar. Mammal Sci. 23:481-495.

PACK, A.A., HERMAN, L.M., CRAIG, A.S., SPITZ, S.S., WATERMAN, J.O., HERMAN, E.Y.K., DEAKOS, M.H., HAKALA, S. \& LOWE, C. 2017. Habitat preferences by individual humpback whale mothers in the Havaiian breeding grounds vary with the age and size of their calves. Anim. Behav. 133:131-144.

PAVANATO, H.J., WEDEKIN L.L., GUILHERME-SILVEIRA F.R., ENGEL M.H. \& KINAS P.G. 2017. Estimating humpback whale abundance using hierarchical distance sampling. Ecol. Model. 358:10-18.

RASMUSSEN, K., PALACIOS, D.M., CALAMBOKIDIS, J., SABORÍO, M.T., DALLA ROSA, L., SECCHI, E.R., STEIGER, G.H. \& ALLEN, J.M. 2007. Southern Hemisphere humpback whales wintering off Central America: insights from water temperature into the longest mammalian migration. Biol. Letters. 3:302-305.

REZENDE, L.F., SILVA, P.A., CIRANO, M., PELIZ, A. \& DUBERT, J. 2011. Mean Circulation, Seasonal Cycle, and Eddy Interactions in the Eastern Brazilian Margin, a Nested ROMS Model. J. Coastal Res. 27(2):329-347.

RODRIGUES, R.R., ROTHSTEIN, L. M. \& WIMBUSH, M. 2007. Seasonal Variability of the South Equatorial Current Bifurcation in the Atlantic Ocean: A Numerical Study. J.Phys. Oceanogr. 37:16-30.

ROSSI-SANTOS, M.R., NETO, E.S., BARACHO, C.G., CIPOLOTTI, S.R., MARCOVALDI, E. \& ENGEL, M.H. 2008. Occurrence and distribution of humpback whales (Megaptera novaeangliae) on the north coast of the State of Bahia, Brazil, 2000-2006. ICES J. Mar. Sci. 65:667-673.

SAGNOL, O. \& REITSMA, F. 2014. Correcting Positional Errors in ShoreBased Theodolite Measurements of Animals at Sea. J.Mar. Biol. 2014:1-8.

SCHAFFAR, A., MADON, B., GARRIGUE, C. \& CONSTANTINE, R. 2009. Avoidance of whale watching boats by humpback whales in their main breeding ground in New Caledonia. SC/61/WW6.

SICILIANO, S., MOURA, J.F., FILGUEIRAS, H.R., RODRIGUES, P.P. \& JEITE JR, N.O. 2012. Sightings of humpback whales on the VitóriaTrindade Chain and around Trindade Island, Brazil. Braz- J. Oceanogr. 60(3):455-459.

SMULTEA, M.A. 1994. Segregation by humpback whale (Megaptera novaeangliae) cows with a calf in coastal habitat near the island of Hawaii. Can. J. Zool. 72:805-8 11 .

SMULTEA, M.A. \& WÜRSIG, B. 1995. Behavioral reactions of bottlenose dolphins to the Mega Borg oil spill, Gulf of Mexico 1990. Aquat. Mamm. 25(3):171-181.

STANISTREET, J.E., RISCH, D. \& VAN PARIJS, S.M. 2013. Passive Acoustic Tracking of Singing Humpback Whales (Megaptera novaeangliae) on a Northwest Atlantic Feeding Ground. PLoS ONE. 8(4):e61263.

TRUDELLE, L., CERCHIO, S., ZERBINI, A.N., GEYER, Y., MAYER, F., JUNG, J., HERVÉ, M., POUS, S., SALLÉS, J., ROSENBAUM, H.C., ADAM, O. \& CHARRASSIM, J. 2016. Influence of environmental parameters on movements and habitat utilization of humpback whales (Megaptera novaeangliae) in the Madagascar breeding ground. Roy. Soc. Open Sci 3:160616.

TYACK, P.L. \& WHITEHEAD, H. 1983. Male competition in large groups of wintering humpback whales. Behaviour. 83:132-154.

VANICEK, P. \& KRAKIWSKY, E.J. 1996. Geodesy: The Concepts. North.2 ed. Elsevier Science Publishers, Amsterdam.

VIDESEN, S.K.A., BEJDER, L., JOHNSON, M. \& MADSEN, P.T. 2017. High suckling rates and acoustic crypsis of humpback whale neonates maximise potential for mother-calf energy transfer. Funct. Ecol. 31(8): 1561-1573.

WHITEHEAD, H. 1983. Structure and stability of humpback whale groups off Newfoundland. Can. J. Zool. 61:1391-1391.

WHITEHEAD, H. \& MOORE, M. J. 1982. Distribution and movements of West Indian humpback whales in winter. Can. J. Zool. 60:2203-2211. 
WILLIAMS, R., TRITES, A.W. \& BAIN, D.E. 2002. Behavioural responses of killer whales (Orcinus orca) to whale-watching boats: opportunistic observations and experimental approaches. J. Zool. 256:255-270.

WINN, H.E. \& REICHLEY, N.E. 1985. Humpback whale Megaptera novaeangliae (Borowski, 1781). In Handbook of marine mammals (S.H. Ridgway \& P. Harrison, eds.). Academic Press, London, pp. 241-273.

WÜRSIG, B., CIPRIANO, F. \& WÜRSIG, M. 1991. Dolphin Movement Patterns: Information from Radio and Theodolite Tracking Studies. In Dolphin Societies - Discoveries and Puzzles (K. Pryor \& K.S. Norris, eds.). University of California Press, Berkeley, pp. 79-111.

ZAR. 1974. Probabilities of Rayleigh's test statistics for circular data. Behav. Res. Meth. Instr. 6(4):450.
ZERBINI, A.N., ANDRIOLO, A., HEIDE-JØRGENSEN, M.P., MOREIRA, S.C., PIZZORNO, J.L, MAIA, Y.G., VANBLARICOM, G.R. \& DEMASTER, D.P. 2011. Migration and summer destinations of humpback whales (Megaptera novaeangliae) in the western South Atlantic Ocean. J. Cetacean Res. Manage. 3(Special Issue):113-118.

ZERBINI, A.N., ANDRIOLO, A., HEIDE-JØRGENSEN, M.P., PIZZORNO, J.L., MAIA, Y.G., VANBLARICOM, G.R., DEMASTER, D.P., SIMÕES-LOPES, P.C., MOREIRA, S. \& BETHLEM, C. 2006. Satellitemonitored movements of humpback whales Megaptera novaeangliae in the Southwest Atlantic Ocean. Mar. Eco-Prog. Ser. 313:295-304.

ZOIDIS, A.M. \& LOMAC-MACNAIR K.S. 2017. A Note on Suckling Behavior and Laterality in Nursing Humpback Whale Calves from Underwater Observations. Animals. 7(51):1-12.

Received: $20 / 04 / 2018$

Revised: $15 / 06 / 2018$

Accepted: 19/07/2018

Published online: 08/10/2018 